\title{
Bewegingswerkwoorde in Van Wyk Louw se poësie
}

\author{
Motion verbs in Van Wyk Louw's poetry
}

\author{
Nerina Bosman \\ Departement Afrikaans \\ Universiteit van Pretoria \\ Suid-Afrika \\ E-pos: Nerina.bosman@up.ac.za
}

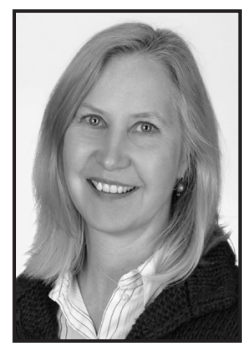

Nerina Bosman

Nerina Bosman doseer voor- en nagraads taalkunde en toegepaste taalstudies aan die Departement Afrikaans, Universiteit van Pretoria. Haar navorsingsgebied is in die eerste plek Afrikaanse leksikale semantiek, binne die teoretiese raamwerk van die kognitiewe semantiek en meer bepaald konseptuelemetafoorteorie. Danksy 'n ruim navorsingstoekenning deur die Nasionale Navorsingstigting is daar in 2014 onder haar leiding begin met ' $n$ navorsingsprojek oor aanspreekvorme in Afrikaans waarin sowel die sosiolinguistiek as die pragmatiek betrek word. Naas artikels verskyn daar, onder haar en prof. Wannie Carstens se redakteurskap, die handboek Kontemporêre Afrikaanse Taalkunde, waarvan 'n tweede uitgawe in 2017 verskyn.
Nerina Bosman teaches undergraduate and postgraduate linguistics and applied language studies at the Afrikaans Department, University of Pretoria. Her area of research covers primarily Afrikaans lexical semantics within the theoretical framework of cognitive semantics and, more specifically, conceptual metaphor theory. Thanks to a generous research grant by the National Research Foundation, a research project on forms of address in Afrikaans, involving both sociolinguistics and pragmatics, was started in 2014 under her leadership. In addition to articles, she has published, along with prof. Wannie Carstens as co-editor, the textbook Kontemporêre Afrikaanse Taalkunde (Contemporary Afrikaans Linguistics), the second edition of which appeared in 2017.

\section{ABSTRACT \\ Motion verbs in Van Wyk Louw's poetry}

Motion verbs form a semantic class of their own. In this article, the meaning extensions and metaphorical foundation of motion verbs in NP van Wyk Louw's poetry are investigated. Cognitive semantics, in which conceptual metaphor theory plays a fundamental part, is used as a theoretical point of departure. Johnson, in The body in the mind (1987), and Lakoff, in Women, Fire and Dangerous Things (1987), examine the nature of image-schematic meaning structures by looking at "the way in which our perceptual interactions and bodily movements within our environment generate these schematic structures that make it possible for us to

\begin{tabular}{|c|c|c|}
\hline $\begin{array}{l}\text { Datums: } \\
\text { Ontvang: 2019-09-25 }\end{array}$ & Goedgekeur: 2020-01-27 & Gepubliseer: Junie 2020 \\
\hline
\end{tabular}


experience, understand, and reason about our world" (Johnson 1987:19). The image schemas identified by Johnson and Lakoff are abstract and embodied, and they play an important role in the new view of a metaphor: "a pervasive principle of human understanding that underlies our vast network of interrelated literal meanings" (Johnson 1987:65).

The concept of change forms part of our understanding of what movement is, and the conceptual metaphor CHANGE IS MOVEMENT underlies linguistic metaphorical expressions derived from this movement metaphor.

An important image schema with motion words is the PATH schema. Lakoff (1987:275) describes the parts of the schema as SOURCE - PATH - GOAL: "Every time we move anywhere there is a place we start from, a place we wind up at, a sequence of contiguous locations connecting the starting and ending points, and a direction."

Miller and Johnson-Laird write as follows about motion verbs: "If one wished to describe the most characteristically verbal of all the verbs, one would turn to the verbs of motion, the verbs that describe how people and things change their places and their orientation in space" (1976:527).

In the context of Louw's poems, which form their own constructed reality, the opposite of movement-namely stillness, rest and death - is often also present.

For the purposes of this analysis, an electronic corpus of Louw's poems was compiled, and word lists and Keywords-in-Context (KWIC) lines were retrieved. Statistically speaking, the word list is quite interesting. It is noteworthy that the corpus is rather small: 49798 running words (tokens) with 7131 types. Compared to other available Afrikaans corpora, such as the Taalkommissiekorpus, this is a really small corpus.

To start the analysis, the semantics of the most frequent motion verb in Afrikaans, gaan ("to go"), was examined. The next step was to identify conceptual metaphors based on the motion verbs found in particular poems. A good example of how movement sometimes infuses a whole poem together with other concepts such as motionlessness and silence, is found in "FRAGMENTE VAN DIE TWEEDE LEWE - 1934" (Die halwe kring 1937). Motion verbs, as well as nouns and adjectives that carry suggestions of movement as their core meanings, are used copiously in this poem: gekom (came), rusteloos (restless), om en om beweeg (move round and round), roering (stirring), vaar (sail), klim (climb), (aan)spoel (wash up/ashore), beur (strain), stuwing (surging), vloed (flood), weggaan (go away), ingegaan (go in).

"Groot ode" (the final poem in Louw's last volume, Tristia, 1962), is widely regarded as one of the greatest and most challenging poems in Afrikaans. The poem starts with the speaker entering a cave (probably the Cave of Almira in Spain, cf. Van Vuuren 2006:283), and moving steadily deeper into the cave - "in die dood se skeur in" (into the crevice of death). The speaker is embarking on a metaphysical quest for enlightenment, which is conceptualised as a continuous, never-ending movement by means of verbs such as sluip (moving stealthily), vaar (sail), rondwaar (wander around), val (fall), loop (walk), instort (plunge in), uitbars (burst out), uitbreek (break out), inloop (walk in).

The PATH image schema (SOURCE-PATH-GOAL) underlies the metaphors identified in "Groot ode", but in the poem the destination, the end of the journey or the quest, is never the focus of the movement; there is, rather, an uncertain destination, a destination still to be reached, and this destination is not yet death. The suggestion at the end of the poem is that the speaker leaves the cave and continues his journey out to sea as a passenger on a white ship:

Die wit skip loop die water in

- betas deur honderde ö

soos skynwerpers aftas -

uit uit die rinkelende hawe uit 
This movement of the ship is linked to the PATH image schema, but with a destination or goal that has not yet been reached:

CAVE

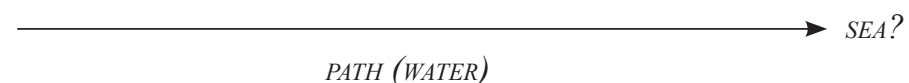

PATH (WATER)

In my reading of the poem the motion verbs point the way to a set of powerful conceptual metaphors that lay the cognitive basis for interpreting and comprehending some of the complex ideas in the poem. These metaphors are:

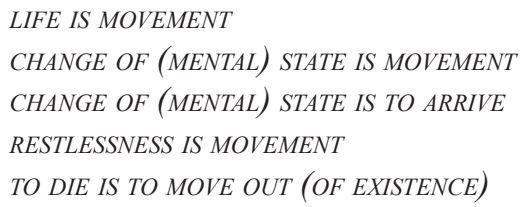

The analysis illustrated that conceptual metaphor theory provides a key to unlock these underlying conceptual metaphors, thereby adding one more reading to the growing body of critical reflection on this great but elusive poem.

KEYWORDS: Van Wyk Louw, motion verbs, going, cognitive semantics, image schemas, PATH, conceptual metaphors, CHANGE IS MOVEMENT

TREFWOORDE: Van Wyk Louw, bewegingswerkwoorde, gaan, kognitiewe semantiek, beeldskemas, PAD, konseptuele metafore, VERANDERING IS BEWEGING

\section{OPSOMMING}

Bewegingswerkwoorde vorm 'n semantiese klas van hulle eie. In hierdie artikel word die betekenis en metaforiese onderbou van bewegingswerkwoorde in NP van Wyk Louw se poësie ondersoek, met die kognitiewe linguistiek, waarvan die konseptuelemetafoorteorie 'n fundamentele deel vorm, as teoretiese vertrekpunt. In aansluiting by die kognitiewe linguistiek word daar aanvaar dat ons verstaan van die werklikheid onder andere nou verweef is met ons beliggaamde ervaring van beweging. Verandering as konsep vorm deel van ons verstaan van wat beweging is en die konseptuele metafoor VERANDERING IS BEWEGING onderlê dan ook metafore wat afgelei word van hierdie oerbewegingsmetafoor. Beweging (die verandering van plek) kan volgens Radden (1995:424) gekategoriseer word as één tipe verandering, saam met ander, soos verandering van tyd en verandering van toestand.

Daar word aangetoon dat betekenis te voorskyn kom deur die PAD-beeldskema (soos wat Johnson en Lakoff aantoon) wat dien as vrugbare brondomein vir konseptuele metafore. Die semantiek van die mees frekwente bewegingswerkwoord in Afrikaans, (en dit is ook in Louw se poësie die mees frekwente), naamlik gaan, word eerstens ondersoek, waarna 'n reeks konseptuele metafore (VERANDERING VAN TOESTAND IS OM 'N BESTEMMING TE BEREIK, VERANDERING VAN GEESTESTOESTAND IS BEWEGING, OM GROTER INSIG TE VERKRY IS OM 'N BESTEMMING TE BEREIK, OM DOOD TE GAAN IS OM UIT TE BEWEEG, LEWE IS BEWEGING) in "Groot ode" geïdentifiseer word.

From the very beginning of our life, and evermore until we die, movement keeps us in touch with our world in the most intimate and profound way. In our experience of movement, there is no radical separation of self from world.

Mark Johnson, The meaning of the body 
Ons was so aan die gaan gewend

Dat ons gemeen het: gáán is goed.

Maar elke gang word: sterf-orent.

Die end is bitter. En dis end.

XXV. Klein variasie op die woord 'gaan'(Tristia)

\section{INLEIDING}

Maar ons skryf nie vir taalkundiges

of vir kundiges nie.

Ons skryf vir die wat kan verstaan

Met hierdie woorde van Louw (soos aangehaal uit Louw se Notaboek deur Pretorius 1984:120 en Van Vuuren 2006:284) in gedagte, maar ook met die hoop dat ons met 'n taalkundige lesing van Louw se gedigte tog ook, of dalk anders, kan verstaan, volg hier nou 'n kognitief-semantiese kyk na en lees van Louw se gedigte deur die lens van bewegingswerkwoorde en die moontlike metaforiek ten grondslag van die tekste.

Dat akkers op sinkdakke (kan) val - maar nie noodwendig breek of kraak nie - en dat vye eers (van 'n boom?) val en dan op 'n ringmuur (kan) breek - ja, wat daarvan? Die taal en die digter laat die twee sinnetjies van die openingsgedig "Klipwerk" aan alle kante oop. En dit is ook heeltemal genoeg - dalk is al wat nodig is vir die leser, dit wat ons bybly, wat deur ons verbeelding vasgehou word, die beeld: 'n sinkdak, 'n ringmuur, 'n boom en die beweging - eers val en dan miskien ook breek - van die harde akkers en die sagte vye.

Dat breek kan volg na val, dat swaartekrag bestaan - dit is so 'n vanselfsprekende deel van ons kennis en belewing van ons ondermaanse werklikheid dat ons skaars daarna oplet. Dat hierdie spesifieke beweging nie begrens word deur 'n toe, geslote ruimte aan alle kante nie - net soos die gedig waarna verwys word - is ook deel van ons kennis. Dinge kan deur 'n ruimte val en val totdat die val gestuit word - met of sonder skade aan die heelheid van die dinge. Hierdie kennis kry konseptuele gestalte in die taal - en in die kognitiewe semantiek word daar aangeneem dat hierdie konsepte wesenlik metafories is.

In wat volg, word die voorkoms van bewegingswerkwoorde en veral die metaforiese onderbou van hierdie werkwoorde in Louw se poësie ondersoek.

Die kognitiewe linguistiek, waarvan die konseptuelemetafoorteorie ${ }^{1}$ 'n fundamentele deel vorm, word as teoretiese vertrekpunt in hierdie artikel gebruik. Die kognitiewe wending, met die nuwe siening dat metafoor nie in die eerste plek 'n talige kwessie is nie, maar te make het met ons hele denksisteem, word reeds opgemerk in Metaphor and thought (Ortony 1979), en in hulle grensverskuiwende boek, Metaphors we live by (1980), verduidelik George Lakoff en Mark Johnson hulle radikaal ander siening van metafoor: metafore is nie die besonderse en soms uitdagende unieke skeppings van poëtiese verbeelding nie, maar die wesensgrond van ons hele konseptuele sisteem. Hierdie siening brei hulle in The body in the mind (Johnson 1987) en Women, Fire and dangerous things (Lakoff 1987) verder uit.

In More than cool reason (1989) toon Lakoff en Turner aan hoe groot digters dieselfde konseptuele instrumente gebruik as alle taalgebruikers, maar ons ervarings op meesterlike, kreatiewe en innoverende wyse belig.

$1 \quad$ Die literatuur rakende die konseptuelemetafoorteorie is geweldig omvangryk. Ek verkies om in hierdie artikel hoofsaaklik na 'n paar seminale tekste te verwys. 
Because metaphor is a primary tool for understanding our world and ourselves, entering into an engagement with powerful poetic metaphors is grappling in an important way with what it means to have a human life. (Lakoff \& Turner 1989:xii)

Die oortuigingskrag van die teorie lê veral in die ervaringsbasis waarop dit tot 'n groot mate steun. Daar is oorvloedige getuienis uit onder meer die sielkunde, die psigolinguistiek en die neuro-wetenskappe dat die basiese aannames van die kognitiewe linguistiek geldig is (vergelyk hier byvoorbeeld die eksperimente waarna Radden (1995) verwys, asook Steen (1999), Brisard e.a. (2001) en Steen (2011) se verwysings na studies oor die prosessering van metafore).

Omdat beweging, en meer nog, die "movement of life", soos wat Johnson (2007) dit stel, een van daardie tipies-menslike beliggaamde ervarings is, word daar kortliks stilgestaan by beweging in die volgende afdeling.

\section{BEWEGING}

\section{Beweging, verandering, beeldskemas en die kognitiewe semantiek}

'n Sentrale uitgangspunt van die kognitiewe semantiek is dat beliggaamde ervaring van fundamentele belang is vir ons konseptuele verstaan van die werklikheid. Beliggaming is trouens ' $n$ fundamentele konsep in die kognitiewe linguistiek. Hierdie begrip hou in dat ons verstaan van die werklikheid spesie-spesifiek is, op grond van die unieke aard van ons liggame (Evans \& Green 2006:44, Gibbs 1999, Jamrozik e.a. 2016). Ons verstaan van hierdie werklikheid is onder andere nou verweef met ons ervaring van beweging, wat gedefinieer kan word as die verandering van plek of stand (Woordeboek van die Afrikaanse Taal - hierna afgekort as WAT - Deel I).

Beweging is 'n fundamentele aspek van die menslike bestaan en deel van ons daaglikse ervaring, soos ook sintuiglike waarneming en die ervaring van swaartekrag, byvoorbeeld. Die ervaring en konsep van beweging word geleksikaliseer in werkwoorde wat gebeure en prosesse verwoord - en hierdie beweging is ook verbind aan tyd of tydsverloop. As die uurwerk kantel, omval en sy wysers stil bly staan, stop ook die tyd.

Verandering as konsep vorm deel van ons verstaan van wat beweging is. Beweging (die verandering van plek) kan volgens Radden (1995:424) gekategoriseer word as één tipe verandering, saam met ander, soos verandering van tyd en verandering van toestand.

Miller en Johnson-Laird (1976:88) beklemtoon die belang van ons waarneming van beweging: "Things that change take priority over things that remain constant: constancy is expected". Beweging dui 'n bepaalde soort verandering aan, naamlik veranderinge in ruimtelike verhoudings. Hierdie verandering speel by mobiele diere soos die mens die belangrikste rol in hulle waarneming: verandering van plek, oriëntasie, of die oogpunt van waaruit gekyk word.

Beweging is die vroegste en mees basiese menslike ervaring en dit lyk asof werkwoorde wat beweging beskryf die eerste geleer word, die meeste gebruik word en konseptueel dominant is (Miller \& Johnson-Laird 1976:527). Miller en Johnson-Laird beskou bewegingswerkwoorde voorts as die mees prototipiese werkwoorde en as 'n belangrike skakel tussen waarneming en taal.

Beeldskemas neem 'n belangrike plek in die kognitiewe linguistiek in. Johnson in The body in the mind (1987) asook Lakoff, in Women, Fire and dangerous things (1987) ondersoek die aard en werking van beeldskematiese betekenisstrukture deur 'n verkenning van "the way in which our perceptual interactions and bodily movements within our environment generate these schematic structures that make it possible for us to experience, understand, and reason about our world" (Johnson 1987:19). 
Die abstrakte beeldskemas word in figuurlike uitbreidings soos hy het nog 'n lang pad om te gaan voor hy sy doel bereik of iets staan in jou pad opgemerk. Vir Johnson (1987) en Lakoff (1987) is 'n beeldskema nie 'n beeld ("image“) of mentale prentjie nie. Dit is 'n manier waarop ons spesifieke ervarings skematies struktureer (Johnson 1987:75).

Johnson (1987:113) lys tipiese beeldskemas soos SKAKELS, SIKLUSSE, SKALE en PAD. PAD as beeldskema is veral belangrik wat bewegingswerkwoorde betref. Die strukturele elemente van die PAD-skema ${ }^{2}$ is ' $n$ bron of beginpunt, ' $n$ doel, bestemming of eindpunt en 'n reeks aaneenskakelende plekke wat die bron met die doel verbind. Grafies stel Johnson (1987:114) hierdie beeldskema as volg voor:

A

PAD

B

\section{Beeldskemas en konseptuele metafore}

Vanweë ons beliggaamde ervaring vorm die bewegingbeeldskema 'n ryk brondomein vir konseptuele metafore. In die kognitiewe semantiek word metafore beskou as karterings vanaf 'n brondomein ('n konkrete domein soos die ervaring van beweging) na 'n doeldomein ('n abstrakte domein soos byvoorbeeld tyd). Hierdie kartering maak dit moontlik dat ons 'n figuurlike of metaforiese talige uitdrukking kan hê soos die tyd vlieg of die vakansie het vinnig verbygegaan.

Aannames in die kognitiewe semantiek is die volgende:

- Beeldskemas struktureer ons ervaring prekonseptueel.

- Ooreenstemmende beeldskematiese konsepte bestaan.

- Daar is metafore wat beeldskemas op abstrakte domeine karteer.

- Die metafore is nie arbitrêr nie, maar word deur strukture inherent aan alledaagse liggaamlike ervaring gemotiveer.

Radden (1995) toon aan dat die onderliggende konseptuele metafoor by bewegingswerkwoorde VERANDERING IS BEWEGING ${ }^{3}$ is. Beweging is 'n vrugbare brondomein vir baie konseptuele metafore, soos onder andere DIE LEWE IS 'N REIS en LIEFDE IS 'N REIS.

Tabel 1 illustreer hoe die metaforiese kartering van LIEFDE IS 'N REIS tussen bron- en doeldomein lyk (soos deur Evans \& Green 2006:295 voorgestel).

\section{Bewegingswerkwoorde}

Bewegingswerkwoorde het 'n kinetiese basis - hulle dui almal 'n vorm van beweging aan - en vorm 'n semantiese veld van hulle eie, maar hierdie veld is nie noodwendig 'n homogene een nie. Deiktiese werkwoorde soos kom en gaan vorm byvoorbeeld op 'n baie spesifieke manier 'n subkategorie van die groot groep bewegingswerkwoorde. Miller en Johnson-Laird beskryf bewegingswerkwoorde as die mees werkwoordagtige werkwoorde: "If one wished to describe the most characteristically verbal of all the verbs, one would turn to the verbs of motion, the verbs that describe how people and things change their places and their orientation in space" (Miller \& Johnson-Laird 1976:527).

2 Lakoff (1987:275) verwoord hierdie beeldskema as SOURCE- PATH- GOAL: "Every time we move anywhere there is a place we start from, a place we wind up at, a sequence of contiguous locations connecting the starting and ending points, and a direction."

3 In die kognitiewe semantiek word die konvensie van kleinhoofletters gebruik om konseptuele metafore voor te stel. 
TABEL 1: $\quad$ Kartering van LIEFDE IS 'N REIS

\begin{tabular}{|l|c|l|}
\hline SourCe: JOURNEY & Mapping & Target: LOVE \\
\hline TRAVELLERS & $\rightarrow$ & LOVERS \\
\hline VEHICLE & $\rightarrow$ & LOVE RELATIONSHIP \\
\hline JOURNEY & $\rightarrow$ & EVENTS IN THE RELATIONSHIP \\
\hline DISTANCE COVERED & $\rightarrow$ & PROGRESS MADE \\
\hline OBSTACLES ENCOUNTERED & $\rightarrow$ & DIFFICULTIES EXPERIENCED \\
\hline DECISIONS ABOUT DIRECTION & $\rightarrow$ & CHOICES ABOUT WHAT TO DO \\
\hline
\end{tabular}

Om te begin met 'n semantiese analise van bewegingswerkwoorde, kan 'n mens na die WAT (Deel I) se definisie van beweeg kyk:

1. "Van plek of stand laat verander; 2. Self van plek of stand verander"

Die besondere kort inskrywing by beweeg (21 reëls) toon reeds aan dat hierdie werkwoord nie so 'n ryk polisemiese struktuur het as byvoorbeeld werkwoorde soos kom (28 kolomme) en gaan (bykans 6 kolomme) nie. Wat menslike (voort)beweging betref, sou 'n mens loop kon uitsonder as die mees prototipiese bewegingswerkwoord in Afrikaans, onder andere op grond van die baie naby sinonieme, wat ook as troponieme getipeer kan word in die sin dat hulle bepaalde maniere van loop uitdruk. Die loop-werkwoorde vorm 'n groot en duidelike groep in Afrikaans: (rond)sluip, rondloop, wandel, stap, hol, hardloop, slenter, drentel, draal, skry, draf, marsjeer, hinkepink, gaan, rondgaan, in- en uitgaan. ${ }^{4}$ Die groep bewegingswerkwoorde het, soos wat tipies is van semantiese velde, nie duidelike grense nie. Werkwoorde wat liggaamsbewegings soos asemhaal, hoes, skouerophaal, glimlag, sluk en dergelike meer aandui, word in hierdie artikel buite bespreking gelaat, omdat die PADbeeldskema nie van toepassing is op hierdie groep nie. Woorde wat emosionele beweging aandui, soos skrik, is ook nie ondersoek in hierdie studie nie.

In die volgende afdelings word die voorkoms en optrede van bewegingswerkwoorde in die poësie van NP van Wyk Louw in oënskou geneem.

\section{BEWEGINGSWERKWOORDE IN LOUW SE POËSIE}

Dat werkwoorde wat die een of ander vorm van beweging uitdruk baie voorkom in Louw se poësie, is geensins uniek of verbasend nie. Bewegingswerkwoorde kom baie voor in taalgebruik en soos hierbo aangetoon is, speel hulle 'n belangrike rol in menslike kognisie. Die een bewegingsmetafoor (VERANDERING IS BEWEGING) is die bron vir 'n ryke verskeidenheid van linguistiese (talige) metafore. In die konteks van bepaalde gedigte, waarin 'n hele taalwerklikheid tot stand kom, is die teenpool van beweging, naamlik bewegingloosheid - stilstand, rus, dood - ook dikwels teenwoordig. Werkwoorde in die Louw-korpus soos sit, stilstaan, stilsit, lê, hang, wag, rus druk hierdie bewegingloosheid byvoorbeeld uit.

\section{Korpusstatistiek}

Alhoewel hierdie artikel nie die oogmerk het om op grond van korpusdata enige ontledings of gevolgtrekkings te maak nie, word daar wel in hierdie afdeling 'n paar interessante aspekte van die Louw-korpus, ook spesifiek met betrekking tot bewegingswerkwoorde, aangebied.

$4 \quad$ Hierdie lysie is sekerlik nie volledig nie. 


\section{Frekwensie}

Vir hierdie ondersoek is 'n elektroniese korpus van al Louw se gedigte saamgestel. Die Louwkorpus bestaan uit 49798 lopende woorde (tekens), maar uit slegs 7131 tipes. $^{5}$

Op grond van 'n woordlys wat deur WordSmith Tools (Scott 2012) gegenereer is, is die mees frekwente werkwoord in die Louw-korpus is (686 trefslae) en wat bewegingswerkwoorde betref, gaan (met 134 trefslae). Kort op gaan se hakke volg kom (106 trefslae). Loop kom nie naastenby so frekwent voor nie (49 trefslae). In Tabel 2 word die bewegingswerkwoorde in die Louw-korpus wat meer as een keer voorkom, gegee. ${ }^{6}$

TABEL 2: Bewegingswerkwoorde wat meer as een keer in die Louw-korpus voorkom

\begin{tabular}{|l|c|}
\hline Werkwoord & Frekwensie \\
\hline gaan & 134 \\
\hline kom & 106 \\
\hline loop & 49 \\
\hline dans & 44 \\
\hline breek & 38 \\
\hline brand & 38 \\
\hline val & 36 \\
\hline sterwe & 31 \\
\hline vlug & 29 \\
\hline stort & 19 \\
\hline stap & 17 \\
\hline gryp & 16 \\
\hline gekom & 15 \\
\hline gegaan & 14 \\
\hline gebreek & 13 \\
\hline spoel & 13 \\
\hline reik & 10 \\
\hline skop & 6 \\
\hline geloop & 6 \\
\hline geval & 6 \\
\hline gegryp & 6 \\
\hline skry & 4 \\
\hline gestort & 3 \\
\hline gevlug & 3 \\
\hline gestryk & 2 \\
\hline & \\
\hline
\end{tabular}

$5 \quad$ Korpuslinguiste werk dikwels met veel groter korpora. Vergelyk byvoorbeeld die groottes van die volgende korpora op VivA se Korpusportaal (http://korpus.viva-afrikaans.org/): Taalkommissiekorpus: 47321344 woorde; Lapa-korpus: 19989190 woorde; Protea Boekhuiskorpus:10 475499 woorde.

6 Soos wat tipies die geval is met elektroniese korpora, beslaan die hapax legomenae (woorde wat net een keer voorkom) in die Louw-korpus meer as die helfte van die korpus: 4122 woorde. 
Die begrip "sleutelwaarde" (in Engels "keyness") is belangrik as 'n mens op soek is na daardie woorde in 'n spesifieke korpus wat uitstaan. Sleutelwoordontleding dui die statistiese beduidendheid van woorde in 'n korpus aan deur die korpus (in hierdie geval die Louw-korpus) te vergelyk met 'n verwysingskorpus (in hierdie geval die Taalkommissiekorpus ${ }^{7}$ ). Om betekenisvolle verskille tussen twee korpora vas te stel, word 'n statistiese meting, naamlik sleutelwaarde, gebruik. Die sagtewareprogram wat gebruik is, WordSmith Tools, maak self hierdie berekening. Die woorde in die doelkorpus word in die lys met sulke sleutelwoorde gelys vanaf die hoogste beduidende verskil. Hoe hoër die sleutelwaarde, hoe groter is die markantheid of opvallendheid van 'n woord in die gegewe korpus.

Onder die eerste 500 sleutelwoorde (woorde wat beduidend meer voorkom in die Louwkorpus as in die Taalkommissiekorpus), is onder andere die volgende: stil, glans, sterwe, smart, helder, vrees, lig, lê, duister, straal, dans, liefde. Hierbenewens het ook bewegingswerkwoorde soos breek, vlug, stort, fletter, spoel, kom, dwaal, loop, waai, val sleutelwaarde - hulle is met ander woorde opvallend baie keer aanwesig in die Louw-korpus. Ook woorde wat die teenpool van beweging uitdruk, soos rus, staan, sit, hang, lê, wag, stil, stilte en roerloos word gevind in die lys sleutelwoorde. Dit lyk dus asof beweging, soos onder andere uitgedruk in baie spesifieke werkwoorde, as sodanig ons aandag opeis in Louw se werk.

\section{Werkswyse}

Sou 'n mens belangstel daarin om die unieke outeurstem, die skrywer se idiolek dus, van nader te ondersoek, is so 'n soektog na sleutelwoorde belangrik. Verskillende digters se korpusse sou dan ook met mekaar vergelyk kon word. Dit was egter nie die doel met hierdie ondersoek nie. Die lys sleutelwoorde is ook nie gebruik om 'n keuse te maak uit al die bewegingswerkwoorde in die Louw-korpus met die oog op nadere ondersoek nie, maar dit is wel vir hierdie artikel betekenisvol dat sekere bewegingswerkwoorde besonder dikwels in hierdie korpus (en dus ook in Louw se poësie) voorkom.

Die elektroniese Louw-korpus is hoofsaaklik gebruik om konkordansiereëls (soekwoorde in konteks) op te roep om die ontleding wat sou volg effe te vergemaklik. Hierdie metode is van groot nut wanneer ' $n$ mens op soek is na semantiese en kollokasionele patrone.

Twee maniere van ontleding is gevolg: die hele oeuvre is eers deurgelees en opvallende aspekte van beweging en/of stilte is aangeteken. Daarna is 'n korpus saamgestel en 'n woordlys aangevra met behulp van WordSmith Tools.

Die semantiek van die mees frekwente bewegingswerkwoord (gaan) is vervolgens ondersoek. Gaan is 'n interessante werkwoord (soos blyk uit die ontleding wat volg). Dit is baie frekwent in Louw se poësie en sou miskien die weg kon aandui na konseptuele metafore in afsonderlike gedigte asook in die korpus as geheel.

Die volgende stap was om konseptuele metafore te identifiseer op grond van die bewegingswerkwoorde binne die groter geheel van die gedigte waarin hulle voorkom. Afsonderlike metaforiese uitdrukkings in spesifieke gedigte is met ander woorde nie ontleed nie - die fokus was om onderliggende metafore wat oor groter teksdele strek, te ontdek.

Die Taalkommissiekorpus word gebruik met erkenning aan die Sentrum vir Tekstegnologie (CTexT), Noordwes-Universiteit, wat die korpus aan my beskikbaar gestel het. 
Laastens is die magistrale "Groot ode" deur die lens van die kognitiewe semantiek gelees en nog 'n lesing, naas dié wat reeds gepubliseer is, is toegevoeg as 'n klein bydrae tot die nimmertanende aandag wat die gedig van lesers eis.

\section{Die kontras beweging en niebeweging}

'n Deurlopende tema in Louw se poësie-oeuvre is die kontras tussen stilte en beweging, rus en onrus. So vra die spreker in "In waansin het ek gevra" (Alleenspraak, 1935) aanvanklik die vrede van die ster, om stil te woon, met God se mag gevang en gebind. Hy wil God tot geen-beweging dwing, en met "ewig-stille oë" op God se "knegskap" kyk. Maar hy verwerp dié dwase rus en vra die reise wat geen einde het nie - hy wil die weë van God gaan en stap. Die laaste strofes van hierdie gedig is gevul met handelinge waarvan sommige selfs gewelddadig genoem kan word: stukkend skeur, uitstrooi, gaan, stap, bewe, soek:

Ek sal ons Wete stukkend skeur en uitstrooi tussen sterre en maan!

Sal ek met so 'n flenterkleed

U weë, o God, U weë gaan?

So sal 'k met naakte liggaam stap

die reis van hierdie wonderlewe, met wonderoë in die lig wat om my van U Wonder bewe.

'n Mooi voorbeeld van hoe beweging soms deur 'n hele gedig stu en ook terselfdertyd in kontras staan met niebeweging en stilte, kry ons in "FRAGMENTE VAN DIE TWEEDE LEWE - 1934" (Die halwe kring, 1937). Bewegingswerkwoorde sowel as selfstandige naamwoorde waarin beweging as die kern van hulle betekenis gesuggereer word, word gebruik: gekom, onrustig om en om beweeg, roering, vaar, klotsing, spoel, beur, stuwing, golwing, vloed, weggaan, ingegaan. Die ontredderde weggaan van die geliefde "tot vreemde enkelheid van weë' lei die spreker in 'n vreemde land van stilte in - en hierdie stilte is nie goed nie, dit is dié van "'n dooie aarde" en "dooie lug" en nie die "ligte vrede-uit-innerlikheid" wat hy nou verloor het nie. In hierdie stilte en verlatenheid, moet "elkeen smartvol en afsonderlik / sy eie blinde weg onwetend, wyd" in "donkere eenselwigheid" gaan - hierdie einde van die pad is die einde van die verhouding. ${ }^{8}$

Bekende motiewe uit Van Wyk Louw se oeuvre is ook hier aanwesig - die alleenheid van die enkeling wat saamhang met die gaan op eie weë en ander paaie, sonder 'n duidelike bestemming.

\section{GAAN IN DIE LOUW-GEDIGTEKORPUS}

Gaan is die mees frekwente bewegingswerkwoord in die Louw-gedigtekorpus (saam met gegaan kom dit 148 keer voor). Die voorkoms en semantiek van hierdie werkwoord word vervolgens in gedigkontekste bekyk.

Met die PAD-beeldskema asook die deiktiese aard van die werkwoord in gedagte, is die volgende indeling in navolging van die WAT-inskrywing by gaan gemaak, alhoewel daar nie altyd skerp grense te trek is tussen die verskillende aspektuele kategorieë wat in die WAT geïdentifiseer word nie. Vergelyk byvoorbeeld ook Miller en Johnson-Laird se opmerking dat

LEWE / LIEFDE IS 'N REIS-metafore onderlê baie duidelik ook die gedig. 
die leksikografiese bewerking van veral deiktiese bewegingswerkwoorde vir woordeboekmakers 'n uitdaging is (Miller \& Johnson-Laird 1976:539).

\section{Duratiewe aspek}

Die WAT (Deel III) dui die eerste betekenisonderskeiding eenvoudig aan as "selfstandig, uit eie wil beweeg, oorwegend in ruimtelike sin". By hierdie groep verander die onderwerp eerstens ruimtelik van plek deur selfstandig te beweeg, maar in 'n uitdrukking soos die tyd gaan snel (die voorbeeldsin is uit die WAT) het ons duidelik ook 'n figuurlike betekenis waar beweging in 'n temporele sin aangedui word. Met hierdie gebruik van 'n abstrakte domein sien ons ook die bekende konseptuele metafoor TYD IS 'N BEWEGENDE VOORWERP aan die werk.

Hierdie betekenisonderskeiding is "gaan sonder meer", waar nóg die vertrekpunt van die beweging, nóg die bestemming in fokus is. Dié betekenis van gaan kom dikwels in die Louwgedigtekorpus voor en die volgende voorbeelde is 'n illustrasie hiervan.

In "Kom vannag in my drome" (Alleenspraak) word die geliefde herhaaldelik versoek om na die spreker te kom en dan sal die geliefdes die ewige skoonheid ken, "tussen die donker dinge waardeur ons lewes gaan".

In "Straat" (Alleenspraak) gaan swaar-gejaste mans met die gloed van die straatvrou se honger oë op hulle.

"Eerste sneeu" (Die halwe kring) is 'n uitstorting van blydskap en vreugde (wat as emosionele beweging gesien kan word) by die aanblik van die wit oopgekelkte aarde - een glinstering waar die nuwe waters gaan: "O hart, sal vreugde hoër gaan", juig die spreker. Gaan word drie keer in hierdie betekenis gebruik, met as laaste die "heerlike gaan" in die rustige dood se hoede. Die emosionele beweging, die wit golf van vreugde, vorm saam met die werkwoorde spoel, breek, en uitgestort'n treffende visuele beeld. Die konseptuele metafoor EMOSIES IS BEWEGENDE VOORWERPE onderlê die gedig.

Ander voorbeelde wat hierdie eerste betekenisonderskeiding illustreer, is die volgende:

en die voete nie altyd so verend en heersend oor die klam aarde en ruislose naalde sou gaan soos 'n jongeling wat haas sonder woorde.

"Herfsnamiddag" (Die halwe kring).

Nog gaan daar sterre op ongewisse bane, dwalend deur die siel;

"Skaduwees van die siel" (Die halwe kring).

Deur watter stiltes moes hy gaan van daadlose vernedering

"Dostojewski" (Die halwe kring).

En nou dat ons gaan in die stil ongenaakbaarheid

elk van sy siel se geheime dinge,

"En nou dat ons gaan" (Alleenspraak).

In hierdie eerste groep val ook die kollokasies van gaan met gang, weg/weë/paaie en ook met stilte en waters op:

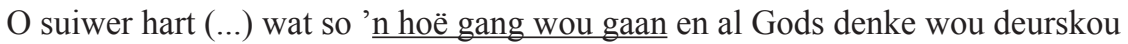

(...)

tot daardie stil en diep bestaan waaroor die sware waters gaan

"O suiwer hart" (Die halwe kring).

maar ek wat gaan waar hoër, kouer paaie lê,

"Opdrag" (Die halwe kring). 
Ek sal ons Wete stukkend skeur en uitstrooi tussen sterre en maan!

Sal ek met so 'n flenterkleed $\underline{\mathrm{U}}$ weë, o God, U weë gaan?

"Profeet" (Die halwe kring).

Ons is 'n blinde en middernagtelike vrees

wat al die ligte dae van ons lewe

die helder weë van die aarde gaan en weet

dat stilte en verskrikking weerskant lê:

"Aan die Skoonheid" (Die halwe kring).

Die bewegende mens word in die kontekste van die gedigte dikwels gekenmerk deur afsydigheid en diepe intellektualiteit, met as een uitvloeisel van die gaan ('n poging tot) die naderbeweeg aan God en 'n "diepe stil bestaan". Die subjek is 'n "aristokratiese enkeling wat binne die massa beweeg", wat in "monastieke afsondering soek", soos wat Pretorius (1984:121) die ek-spreker in "Groot ode" beskryf.

\section{Inchoatiewe aspek}

Die WAT onderskei 'n tweede betekenisgroep wat die inchoatiewe en ook deiktiese aspek van gaan se betekenis weergee: beweging weg van 'n vertrekpunt, in teenstelling met kom. Die begin van die handeling, asook die wegbeweeg van 'n punt af, deur die bewegende ego in deiktiese sin, is in fokus.

Wanneer die bose in "Ballade van die bose"(Gestaltes en diere) vra: "O waar sal jy gaan en met watter skip?" is die beginpunt duidelik - weg uit die stad wat brand - maar die eindbestemming is onbekend, onseker en dui op onheil, want die bose gaan saam "soos 'n vrou aan jou hand".

\section{Perfektiewe aspek}

Die derde betekenisonderskeiding wat in die WAT onderskei word, druk beweging $\boldsymbol{n a}$ 'n plek of'n punt toe, na 'n bestemming of doel, of in 'n gegewe rigting uit.

Nou was sy liggaam bruin soos grond

en tot die aarde kon hy gaan

om tussen die eenvoudige dinge

weer regop en weer rein te staan

"Nou was sy liggaam"(Gestaltes en diere).

In Louw se poësie is hierdie bestemming dikwels nie 'n fisiese plek nie, maar byvoorbeeld die dood:

Daar kom in my 'n stil vermoede

Dat alle lewe só sy volheid kry

En heerlik gaan in die rustige dood se hoede

"Eerste sneeu" (Die halwe kring).

Jy gaan - jou gees bly oor my soos 'n wolk op hoë berge

"Nietzsche" (Die halwe kring).

Die einde van die pad kan ook tot berusting "sonder gedagtenis" lei, soos in "Sou dit nie beter wees nie" (Alleenspraak). 
Die spreker in "Ballade van die drinker in sy kroeg" (Gestaltes en diere) smag na beweging weg van waar hy vassit in die glans van nikkel en staal en gevange hang in spieëls: "As ek deur daardie deur kan gaan, dan vind ek dalk wat ek wou hê."

In "Die hond van God" (Gestaltes en diere) gaan die inkwisiteur saam met die mense wat hy folter na dieptes van liggaamlike en geestelike pyn: "maar ék gaan in die parskuip met hulle saam" sê hy, en hy gaan ook in God se "duister waters" mee.

Konseptuele metafore wat verbind word met die beeld-skema OORSPRONG / BRON - PAD DOEL / BESTEMMING en wat reeds in hierdie klein bestekopname van gaan raakgesien is, is die volgende:

\author{
VERANDERING VAN (GEESTELIKE TOESTAND) IS BEWEGING \\ SOEKE NA INSIG IS BEWEGING \\ DIE VERKRYGING VAN INSIG OF BERUSTING IS OM TE ARRIVEER \\ DIE VERKRYGING VAN INSIG OF BERUSTING IS OM OP TE HOU BEWEEG / STILSTAND \\ LEWE IS BEWEGING \\ DOOD IS OPHOU BEWEEG
}

Die laaste afdeling probeer (sonder twyfel ambisieus) om te kyk of die laaste gepubliseerde gedig van Van Wyk Louw, "Groot ode", as geheel ook iets van die dinamiek en konseptuele metaforiese onderbou van bewegingswerkwoorde bevat.

\title{
"GROOT ODE"
}

Werkwoorde wat die een of ander vorm van beweging in die gedig aandui, maar meer nog, konseptuele metafore van beweging, staan in die fokus van die ontleding wat volg. Die vrae wat gevra is voordat met die ontleding begin is, is eerstens, of daar, benewens die talige uitdrukkings waarin bewegingswerkwoorde gebruik word, ook onderliggende konseptuele metafore geëien kan word; en tweedens, of so 'n konseptuele metafoor (of metafore) kan bydra tot 'n verstaan van die teks. Die fokus was nie afsonderlike talige uitdrukkings wat as metafore begryp word, soos byvoorbeeld "Laat daar wit oor gevou word" (reël 35) nie, alhoewel sulke kreatiewe metafore wel die weg aandui na konseptuele metafore.

"Groot ode", die indrukwekkende slotgedig van 'n indrukwekkende en uitdagende bundel, is 'n groot, majestueuse en moeilike gedig. Om die kritiese ontledings wat al van hierdie gedig gedoen is selfs net oorsigtelik in oënskou te neem, val buite die bestek van dié artikel. Daar word met die volgende oorsig volstaan.

"Groot ode" word allerweë beskou as een van die grootste, miskien selfs dié grootste gedig in Afrikaans. In Tristia in perspektief verwys Van Vuuren na die ontvangs van Tristia deur kritici na die verskyning van die bundel in 1962 (Van Vuuren 1989:122 e.v.). AP Grové beskryf die bundel as "verwikkeld" en "diepsinnig" en beklemtoon die rykheid van die teks; Opperman beskryf "Groot ode" as "een van die durwendste en waaghalsigste eksperimente in Afrikaans" en Antonissen noem Tristia "die grootste bundel poësie tot dusver". Van Vuuren, wat hierdie bundel op meesterlike wyse ontsluit, plaas "Groot ode" in die sentrum van Tristia en noem dit "nog steeds een van die belangrikste hoekstene van die Afrikaanse poësie" (Van Vuuren 1989:123) en "nog steeds die intellektueel-uitdagendste Afrikaanse gedig, wat die leser se houvas bly ontglip" (2006:282). Sy sluit haar 2006-artikel af met die opmerking: "Die uitdaging van "Groot ode" bly waarskynlik dié kreatiewe en intellektuele hoogtepunt van die Afrikaanse letterkunde” (Van Vuuren 2006:294). 
"Groot ode" is té groots, té ryk, té omvangryk en ten slotte té dig geweef om volledig in ander woorde as dié van die teks self omvat te kan word. In die volgende lesing probeer ek slegs om één tema in die gedig - die eindelose soeke soos wat Pretorius (1984:125) dit noem - as't ware op die voet deur die gedig te volg en om in my eie soeke onderliggende konseptuele metafore te identifiseer. Buite hierdie een kyk om bly die gedig oop vir 'n veelvoud van naasliggende, "benaderende maar nooit bereikende" begrype nie - om die titel van Pretorius se 1979-artikel, later opgeneem in haar bundel Ryk domeine (1984) aan te haal. Geen een kyk of interpretasie kan waarskynlik hierdie magistrale gedig volledig oopsluit nie.

Die gedig is moeilik; verleidelik dog misleidend toeganklik vanweë die kort, stip versreëls en die woorde wat oor die algemeen maklik begryplik in hulle basiese betekenisse ${ }^{9}$ is. Agter hierdie oënskynlike eenvoud lê daar 'n "sintetiserende, elegiese perspektief op 'n hele menselewe" (Antonissen 1963:45 soos aangehaal deur Van Vuuren 1989:122), en meer as dit, ook op die lang, veelbewoë Westerse geskiedenis.

Pretorius (1984:119) haal Fowler (1973:131) se omskrywing van die ode as "the most elevated and complicated species of lyric" aan en noem "Groot ode" na aanleiding hiervan inderdaad 'n hoogs gekompliseerde gedig, onder andere vanweë die ingewikkelde filosofiese redenering, die moeilike taalstruktuur en die onbekende verwysings na sekere oerbronne. Verder aan noem sy die gedig 'n "intrinsiek moeilike werk" (Pretorius 1984:120). Sy bied, ten spyte hiervan, danksy 'n sekere "koppige volharding en waagmoed", 'n uiters boeiende en indrukwekkende lesing van die gedig aan.

Opvallend in Pretorius se diskoers oor die gedig, is dat sy self die woorde beweeg en beweging ' $n$ hele paar keer gebruik. Sy beskryf die ek-spreker as iemand wat sluipend en tastend-ontdekkend in die grot, "die dood se skeur" inbeweeg. Die metafisiese soeke na verligting en verheldering word in die gedig as 'n nooit-ophoudende voortbeweeg gekonseptualiseer, onder andere deur die gebruik van bewegingswerkwoorde soos insluip, rondwaar, voortgaan, loop, duik-in, vaar, aanleun, spoel, wegvoer, val, stort. Ook ander entiteite as die spreker beweeg, val, bars en breek uit.

Kontrapuntaal ${ }^{10}$ teenoor hierdie soeke-as-beweging staan die stilte, die vastheid, water wat in ys gestol het. Van reël 99 tot 146 is daar aandag aan ys, aan stolling, aan bewaring van onder andere lieflike dinge, wat lieflik bly onder die ys, maar die ys is ook 'n landskap waarin die mens verdwaal, altyd in linkerkringe loop - dus nie na 'n eindpunt toe nie.

Stilte (soos van 'n toegeysde aarde) in die konteks van "Groot ode" is nie goed nie; die dood is per slot van sake niebeweging, in die letterlike sin van 'n hart wat ophou klop. Sterweself is net skynbaar'n handeling; groot stede lê roerloos onder yskappe; die aarde gaan stiller word, sê die soekende, voortbewegende spreker, maar ons denke sorg dat ons, "die Gees:/ die Warende rondom ons aarde" nóóit toegesneeu sal word nie (reëls 130-132).

$\mathrm{Na}$ hierdie interlude oor ys (en stilte, niebeweging), bepeins die digter die aard van God. Die tekening van God in "Groot ode" is dikwels dié van 'n Wese wat self beweeg, maar wat

$9 \quad$ "Groot ode" het 1373 lopende woorde, met 575 tipes -'n "skraal" teks wat woordeskat betref en wat ook klein lyk op die bladsy self, maar hoe misleidend is so 'n opvatting nie!

10 Pretorius (1984) wys op die "boeiende verwantskap" tussen "Groot ode" en Beethoven se B-molmajeurstrykkwartet. Sy verwys veral na die "enigmatiese" Finale, die "Grosse Fuge", waarin Beethoven die musikale konvensies van die fuga as't ware weggevreet het. Ook Van Vuuren (2006:287) merk op dat die gedig "veel weg (het) van 'n musikale fuga-konstruksie (soos in 'n Griekse koor of korale ode)". 
ook dinge láát beweeg. Sy woorde laat supernovas uitbars, Hy is 'n vinger, ${ }^{11}$ hand of handgebaar - en sy hand laat dinge gebeur. Dié bars en uit-breek kenmerk Hom, dit is Syne, dit is sy ware aard. Pretorius (1984:129) verwys na Copplestone (1975:131) wat God beskryf as "the first unmoved mover, first efficient cause" - in konseptuele terme, die oer-oorsaak en begin van alle beweging. Teenoor God as beweger stel die spreker 'n ander (Griekse) god, wat nie pyn het nie, wat ' $n$ ewige watervlak sonder rimpel is, selfvoldaan in eie beskouing. Hierdie onbeweeglikheid, die rustige almag, is wegwerplik - en die spreker keer hom daarvan af.

Beelde van water (ook water wat stol tot ys) begelei dikwels die beweging. Die op-wegwees, die laat gaan van sekerhede lei tot water waarin geduik kan word, na beweging onder in die water in - nie om bo-op die water te drywe nie - en ten slotte om op die water uit te vaar, die verwagting van reël 44 te verlaat en weg te beweeg van die vastheid van die land.

Die spreker hou aan beweeg, ook terwyl die wêreld stiller word. Hierdie stilte is 'n klankstilte, nie die stilte van niebeweging nie, maar teen die einde van die gedig roep 'n voël in die nag in en deurbreek ook hierdie skynbare rustigheid, net soos die wit skip wat, sonder haas, maar doelgerig, die water inloop.

Onderliggend aan die metafore wat reeds hier bo geïdentifiseer is, is die PAD-beeldskema met sy onderdele BRON - PAD - DOEL OF BESTEMMING. Ons baie basiese beliggaamde ervaring van beweging maak dit moontlik dat hierdie beeldskema as brondomein vir 'n aantal aaneenskakelende metaforiese karterings dien.

Die een prominente aspek van die betekenis van gaan soos aangetoon hier bo, is dat die inchoatiewe aspek dui op die begin van 'n aksie, wat waarskynlik voorafgegaan word deur 'n ander aksie. In "Groot ode" se geval besoek die ek-spreker die grot van Almira in Spanje na 'n mislukte liefdesverhouding wat hom onder andere bitter en ontnugterd laat (Van Vuuren 2006). Die ingaan in die grot is voel-voel, en dit wat hopelik lig sal bring, is die intellektuele soeke na antwoorde op groot lewensvrae, na die rede vir pyn, na die wese van God, na die sin van die menslike bestaan. Die spreker beweeg weg van sy beginpunt, in die rigting van 'n onseker bestemming in 'n donker grot.

Deel van die soektog is onsekerheid, ook onsekerheid oor die eindbestemming. Die wit skip (met die spreker as passasier?) vaar uit, loop die water in vanaf die beginpunt, uit die rinkelende hawe, die sekere vertrekpunt, uit, in teen die wind; en die voël wat ten slotte die nag in roep is nie 'n soet nagtegaal nie, maar onrus, nie stilwees nie. Die beeldskema hier dek nie die volledige PAD-skema nie: daar is 'n duidelike beginpunt, maar 'n onsekere eindbestemming - die oop see?

GROT OOP SEE?

PAD: WATER

Die metaforiese karterings wat die tema van soeke na insig onderlê, is van die brondomein van beweging na die doeldomein van 'n verandering van geestelike toestand. Dit mag waandenke wees, sê Louw elders in "Klein variasie op die woord 'gaan'” dat dié beweging, die gáán, 'n ander bestemming, eindpunt, end, kan hê as die dood, dat die veranderde toestand as sodanig wenslik is. Tog is dit juis die innerlike reis, die kom tot insigte, en miskien 'n klein bietjie sekerheid wat die spreker verder laat beweeg, eers laat afdaal dieper in die grot in en uiteindelik laat uitvaar.

11 Miskien is dit nie vergesog om hier Michelangelo se bekende skildering van God in die Sistynse Kapel as interteks voor die gees te roep nie. God steek sy vinger, nadat hy Eva geskep het, na die slapende Adam uit om hom wakker te maak, te laat beweeg. 
Die BRON in ruimtelike sin, die OORSPRONG of beginpunt, is die fisiese en geestelike toestand waarin die ek-spreker hom bevind voordat die ontdekkingstog dieper die grot in begin, voor die verandering van plek en geestelike toestand intree.

Die DOEL of BESTEMming word gekarteer op die geestelike of fisiese toestand nadat ' $n$ volgende plek bereik is, of nadat insig verkry is. In "Groot ode" word hierdie bestemming nie bereik nie, die ek-spreker is as't ware altyd op weg na, nog steeds besig om God se weë te gaan, op hoër, koue paaie te gaan. Die PAD dui die oorgang aan, 'n tussenfase, wat altyd gekenmerk word deur onrus. Daar is wel 'n skemering van insig in die menslike bestaan, die antwoord op die vraag na die rede vir die bestaan van pyn skyn daar te wees (dit is nodig), die wesensaard van die mens is dat hy 'n "walg" is, stilte is nie wat begeer moet word nie: nie die selfvoldane rus nie, maar die ónrus lei tot geestelike verandering en insig. Die oop einde - geen bestemming nie, maar 'n onbegrensde uitvaart uit die grot uit, die see in - laat die leser wel met 'n vreemde gevoel van bevrediging - die reis na heiligheid en volledigheid word voortgesit. $^{12}$

Kan dit bloot toevallig wees dat die gedig begin met die (onsekere, tastende) inbeweeg in 'n (omslote en begrensde) ruimte in en sluit met die beeld van die wit skip wat die water inloop, uit die beskermde, beskutte hawe uit met as begeleiding van die vaart die onrus van die voël wat roep? In konseptuele sin is dit sekerlik nié toevallig nie. Menslike kognisie laat juis toe dat hierdie magistrale gedig, in 'n poging om 'n greep te kry op die lewe en die ganse menslike bestaan, kan staatmaak op 'n ryk, beliggaamde konseptuele onderbou van metafore waar die een metafoor kan lei tot ander in 'n diggeweefde musikale beweging.

Die reeks aaneenskakelende konseptuele metafore wat "Groot ode" onderlê, kan as volg voorgestel word:

Die sentrale konseptuele metafoor, wat alle bewegingswerkwoorde onderlê, is VERANDERING IS BEWEGING. Dié metafoor gee aanleiding tot metafore wat saam die tema van soeke onderlê:

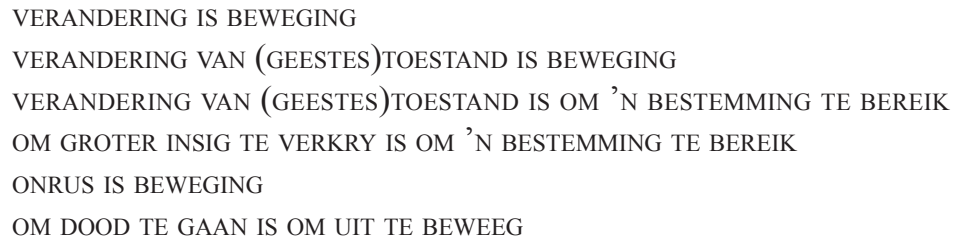

Is hierdie laaste metafoor ook die noodwendige einde van "Groot ode"? Dit lyk tog nie so nie. Die eindbestemming, wat dit ook al mag wees, is nooit die fokus in hierdie gedig nie. Die begin en die pad, die reis self - dit is waaroor dit gaan. Daar is ook die koppige weiering om te rus, die uitskreeu na ánders as hy is. Daar word nie aangekom by 'n bestemming in "Groot ode" nie. ${ }^{13}$

Nog 'n konseptuele metafoor kan betrek word by die ontleding. Johnson (2007:19) stel die verband tussen lewe en beweging ondubbelsinnig duidelik: "Life and movement are inextricably connected. Movement is one of the conditions for our sense of what our world is like."

12 Die slot van "Groot Ode" roep as interteks ook die vaart van die seun in sy skippie in "Die wind in die baai het gaan lê"op (IX in die afdeling "Tristia" in Tristia).

13 Dit is dan ook insiggewend dat daar meer gegaan as gekom word in Van Wyk Louw se hele gedigte-oeuvre. 
En as mens wel die metafoor LEWE IS BEWEGING teenoor DOOD IS DIE EINDE VAN BEWEGING in "Groot ode" raaklees, kan ons een belangrike aanname van die kognitiewe linguistiek - dat ons op 'n beliggaamde wyse betekenis skep - aanvaar.

\section{SAMEVATTING}

In hierdie artikel is die semantiek van bewegingswerkwoorde in NP van Wyk Louw se poësie ondersoek in die lig van die kognitiewe semantiek. Daar is op soek gegaan na konseptuele metafore wat met beweging ('n baie basiese en bekende menslike ervaring) verband hou en wat die metaforiese onderbou van een bepaalde gedig - "Groot ode" - sou kon belig. 'n Netwerk van subtiele en komplekse betekenisse wat deur middel van die konseptuele metafore, soos bemiddel deur die PAD-beeldskema, na vore tree, is aangetoon en die bydrae van 'n kognitief-semantiese kyk na Louw se poësie is geïllustreer. Ook die groot digter se denke, wat wesenlik metafories is, is verbonde aan en kry gestalte in die taal - dikwels ondeurgrondelik, maar soms ook verrassend en heerlik helder.

\section{BIBLIOGRAFIE}

Brisard, F., Frisson, S. \& Sandra, D. 2001. Processing unfamiliar metaphors in a self-paced reading task. Metaphor and Symbol, 16 (1\&2):87-108.

Casad, Eugene H. (ed.). 1995. Cognitive linguistics in the redwoods. Den Haag: Mouton de Gruyter.

Evans, V. \& Green, M. 2006. Cognitive linguistics. An introduction. Edinburgh: Edinburgh University Press.

Gibbs, R.W. 1999. Taking metaphor out of our heads and putting it in the cultural world. In Gibbs \& Steen (eds). Metaphor in cognitive linguistics. Amsterdam: John Benjamins, pp. 145-166.

Jamrozik, A., McQuire, M. \& Chatterjee, A. 2016. Metaphor: Bridging embodiment to abstraction. Psychonomic Bulletin and review, 23(4):1080-1089.

Johnson, M. 1987. The body in the mind. The bodily basis of meaning, imagination, and reason. Chicago: The University of Chicago Press.

Johnson, M. 2007. The meaning of the body. Aesthetics of human understanding. Chicago: The University of Chicago Press.

Lakoff, G. \& Johnson, M. 1980. Metaphors we live by. Chicago: The University of Chicago Press.

Lakoff, G. 1987. Women, fire and dangerous things. What categories reveal about the mind. Chicago: The University of Chicago Press.

Lakoff, G. \& Turner, M. 1989. More than cool reason. Chicago: Chicago University Press.

Louw, N.P. van Wyk. 1935. Alleenspraak. Kaapstad: Nasionale Pers.

Louw, N.P. van Wyk. 1937. Die halwe kring. Kaapstad: Nasionale Pers.

Louw, N.P. van Wyk. 1941. Raka. Kaapstad: Nasionale Boekhandel.

Louw, N.P. van Wyk. 1942. Gestaltes en diere. Kaapstad: Tafelberg.

Louw, N.P. van Wyk. 1954. Nuwe verse. Kaapstad: Tafelberg.

Louw, N.P. van Wyk. 1962. Tristia. Kaapstad: Human \& Rousseau.

Miller, G.A. \& Johnson-Laird, P.N. 1976. Language and perception. Cambridge: University Press.

Ortony, A. (ed.). 1979. Metaphor and thought. Cambridge: Cambridge University Press.

Pretorius, R. 1984. Benaderend maar nooit bereikend - 'n voorlopige begryp van "Groot ode" (NP van Wyk Louw). In Pretorius, R. Ryk domeine. Opstelle oor die Afrikaanse poësie. Kaapstad: Human \& Rousseau, pp. 117-132.

Radden, G. 1995. Motion metaphorized: The case of coming and going. In Casad (ed.). Cognitive Linguistics in the redwoods. Den Haag: Mouton de Gruyter, pp. 423-458.

Scott, M. 2012. WordSmith Tools version 6. Stroud: Lexical Analysis Software.

Steen, G. 1999. Analyzing metaphor in literature: with examples from William Wordsworth's "I wandered lonely as a cloud”. Poetics Today, Metaphor and beyond: New Cognitive Developments, 20(3):499522. 
Steen, G. 2011. The contemporary theory of metaphor - now new and improved! Review of Cognitive Linguistics, 9(1):26-64.

Van Vuuren, H. 1989. Tristia in perspektief. Kaapstad: Vlaeberg.

Van Vuuren, H. 2006. Tussen "Grense" en "Groot ode": 'n klein essay oor die poësie van N.P. Van Wyk Louw (1906-1970). Tydskrif vir Geesteswetenskappe, 46(3):279-90.

\section{WOORDEBOEKE}

Woordeboek van die Afrikaanse taal. Dele I (A-C) en III (G). Pretoria: Die Staatsdrukker. 